\title{
América Latina: Uma Igreja Missionária
}

\author{
Mario de França Miranda SJ
}

De 13 a 31 de maio deste ano reuniram-se na cidade de Aparecida, Santuário Mariano no Estado de São Paulo, visitado anualmente por quase $9 \mathrm{mi}-$ lhões de peregrinos, os participantes da V Conferência Geral do Episcopado Latino-americano e Caribenho. Estavam previstos 160 membros, em sua grande maioria eleitos em suas respectivas Conferências Episcopais, além de 82 convidados (sacerdotes, diáconos permanentes, religiosos e religiosas, leigos e leigas, superiores maiores e representantes de movimentos). Havia ainda observadores de outras Igrejas e comunidades cristãs, assim como a presença de quinze peritos. Naturalmente nem todos os eleitos ou convocados puderam comparecer por diversas razões. As sessões de trabalho tiveram lugar num amplo espaço situado em baixo da Basílica de Nossa Senhora Aparecida, dotado de auditório, salas para os diversos grupos, equipamento eletrônico adequado, que muito facilitaram os trabalhos empreendidos.

Objetivo desta V Conferência era repensar a tarefa da Igreja neste Continente diante das grandes mudanças sociais, políticas, econômicas e mesmo religiosas, ocorridas de 1992 (Conferência de Santo Domingo) até nossos dias. A história nos ensina que a Igreja, mesmo mantendo sua identidade teológica através dos séculos, assume sempre uma configuração institucional determinada para poder ser na sociedade um autêntico sacramento da salvação de Jesus Cristo. Novos desafios culturais, novas conjunturas sociais, novas problemáticas pastorais pedem da Igreja novas atitudes, estru- 
turas e ações pastorais. As rápidas e sucessivas mudanças socioculturais experimentadas no continente latino-americano explicam a razão de ser da $\mathrm{V}$ Conferência Geral.

Embora a Europa costume ver a América Latina como um continente homogêneo, embora constituído de muitos países, a experiência de qualquer participante em Aparecida deve ter sido outra. Pois a riqueza humana e cultural dos vários povos se fez presente de modo marcante através das pessoas e de suas intervenções. Ao mesmo tempo em que se podia observar uma linguagem básica, em grande parte devido à raiz cultural católica destes povos, notava-se igualmente seu modo peculiar de considerar a realidade e viver a fé cristã. Graças ao clima de diálogo e de liberdade que se instalou desde os primeiros dias, esta riqueza de experiências e de preocupações diversas irá se refletir no documento final, que procurou sempre ser fiel ao que cada um expressava.

Este ponto irá marcar mesmo a própria metodologia de trabalho. Embora todos tivessem em mão a Sintese das reações provindas das diversas Conferências Episcopais ao documento preparatório, optou-se por partir do zero, como se diz. Os primeiros grupos aleatoriamente constituídos deveriam elencar os temas mais importantes e prioritários. A partir deles pode ser posteriormente elaborado um esquema de trabalho, que gerou tensões e que custou horas preciosas, antes que se chegasse a um acordo, sobretudo com relação ao método ver, julgar e agir. No fim se optou por uma introdução positiva que manifestasse, através de um louvor e agradecimento, a alegria da fé católica destes povos (cap. I). O olhar sobre a realidade social, política e econômica, é um olhar qualificado, a partir da fé e constitui uma rica descrição deste continente. Segue-se a consideração sobre a própria realidade eclesial, com suas luzes e suas sombras (cap. II).

Como já havia acontecido em Puebla e Santo Domingo a alocução inaugural do papa vai ser programática e decisiva para as reflexões posteriores. Deixando entrever que certas disputas de cunho ideológico já estavam ultrapassadas e que novas ameaças muito sérias pairavam sobre a Igreja, Bento XVI chama a atenção para a centralidade da pessoa de Jesus Cristo como caminho, verdade e vida (Jo 14,6), para a importância de uma antropologia aberta ao Transcendente, para uma correta compreensão da realidade a partir de Deus, "realidade fundante" de todo o criado. Palavras incisivas numa época de tanto relativismo, de tanta insegurança, de tanto medo do futuro! Mas Bento XVI não se deixou prender num espiritualismo etéreo e desencarnado. Ele olhou de frente para a realidade latino-americana e caribenha. Daí suas palavras: "A evangelização vai sempre unida à promoção humana e à autêntica libertação cristâa" (Discurso Inaugural 3). Uma terceira linha mestra de sua 
alocução está na palavra missão. Historicamente se explica que a falta de sacerdotes tenha transplantado a cristandade européia para a América Latina através da piedade medieval da Península Ibérica. Esta consistia numa devoção, popular, festiva, voltada para os santos patronos, mas que conseguiu na sua simplicidade manter a fé católica neste continente. Por outro lado, deixa transparecer um déficit de evangelização real e grande passividade do laicato diante do clero. Para Bento XVI a renovação deve provir de um laicato consciente, ativo, missionário, já que "discipulado e missão são como as duas faces de uma mesma moeda" (Ibid. 3). Este élan missionário deverá atingir toda a Igreja renovando-a e revitalizando-a (Ibid. 2).

As contribuições dos participantes nas 15 subcomissões temáticas, resumidas pelos respectivos relatores, constituíram o material básico para a primeira redação do texto de Aparecida. As intervenções em plenário e a discussão nas respectivas comissões foram aprimorando-o, dando lugar a redações mais aperfeiçoadas do documento. Estas aconteceram, sobretudo, nos últimos dias sob pressão de um tempo cada vez mais escasso e com o trabalho heróico e abnegado dos bispos membros da comissão de redação. Procurou-se então preencher lacunas, eliminar as repetições, uniformizar o estilo. O que nem sempre se conseguiu pela falta de tempo.

Porém mais do que o texto produzido, a V Conferência Episcopal de Aparecida foi marcada por um clima de fraternidade, de paz e de estima mútua, que experimentou um crescendo conforme se sucediam os dias, os encontros e um maior conhecimento pessoal. Centrados na mesma fé, responsáveis pela mesma Igreja, às voltas com problemas semelhantes, os bispos logo se sentiram próximos entre si, apesar da distância física de suas dioceses. A convergência dos pontos de vista e dos juízos vai se demonstrar na aprovação massiva do texto final. Ajudou também, e muito, o local por ser um santuário mariano popular. $\mathrm{O}$ calor e a fé dos peregrinos, especialmente, nos finais de semana, contagiaram fortemente os participantes de fora do Brasil. A presença atuante de Nossa Senhora Aparecida foi sentida por todos.

Naturalmente ainda é cedo para uma avaliação mais profunda do texto, ainda não definitivo, e a ser apresentado a Sua Santidade Bento XVI no dia 11 de junho. Mas podemos arriscar uma primeira leitura, sujeita a correções, que destaque os eixos maiores deste documento. Estes já se encontram incluídos no tema geral desta Conferência: "discípulos e missionários de Jesus Cristo para que n'Ele nossos povos tenham vida". Destaquemos alguns deles.

Eu começaria pela pessoa de Jesus Cristo, pois o discipulado depende de uma compreensão correta da pessoa de Jesus Cristo. Tarefa nada fácil, pois nos últimos anos a Igreja experimentou tendências redutoras em algumas cristologias que, ou acentuavam de tal modo a dimensão histórica de sua 
vida que deixava em segundo plano sua divindade, apresentando-o mais como um profeta da transformação social, ou enfatizavam de tal modo sua divindade que quase ignoravam sua humanidade e sua história concreta. Apesar da alocução inaugural de Bento XVI se colocar num patamar acima dessas desavenças, ela não foi suficiente para apaziguar os ânimos e desfazer mal-entendidos. Mas mesmo carecendo de uma cristologia explícita, como muitos desejariam, existe certamente no texto uma cristologia, implícita, ampla, que faz jus às diversas reivindicações dos participantes.

A fé em Jesus Cristo como Filho eterno do Pai, entrando em nossa história para nos salvar, constituindo o caminho para que cheguemos à verdade e à vida, vem afirmada e explica a razão última da nossa alegria e da nossa esperança (cap. III). A vocação cristã, vista como um chamado ao seguimento de Jesus Cristo, acentua a necessidade da nossa união com Ele e da participação em seu destino, a centralidade do amor fraterno e o compromisso com sua missão (cap. IV). O discípulo de Cristo vive assim em comunhão com a Santíssima Trindade, daí derivando a comunhão que tem com os demais discípulos. Deste modo, o cristão vive sempre numa comunidade eclesial, que tem seu ponto máximo na celebração eucarística. A diversidade dos carismas e ministérios não rompe, mas enriquece esta comunhão como unidade na diversidade (cap. V). A formação do discípulo missionário tem como ponto de partida o encontro pessoal com Jesus Cristo, através da Igreja, da Palavra de Deus, da eucaristia, da oração pessoal e comunitária, dos irmãos na comunidade, dos pobres (cap. VI).

A terceira parte do documento de Aparecida abrange o tema da "vida de Jesus Cristo para nossos povos". O tema vida é amplo nas Sagradas Escrituras, pois fala da vida de Deus em nós, da vida eterna, da vida na caridade, da vida nova em Cristo. Mas fala igualmente da vida proporcionada por Jesus Cristo ao longo de seus dias na condição humana, quando dava vida nas curas corporais, na inserção social, no perdão dos pecados, na proximidade com os pobres e com os excluídos. Esta vida diz respeito a todas as dimensões da existência humana pessoal, familiar, cultural e social. Não atrofia, e sim plenifica a pessoa humana conduzindo-a a verdadeira felicidade. Levar esta vida para todos é a missão principal da Igreja, na vivência da caridade, na partilha dos bens, no serviço ao outro, na entrega da própria vida. Naturalmente esta tarefa exigirá uma conversão pastoral de todos os membros da Igreja, uma reforma também das instituições eclesiais, um voltar-se também para outros continentes (cap. VII).

Esta cristologia que parte do tema da vida retoma no capítulo seguinte a noção do Reino de Deus, central nas palavras e nas ações de Jesus Cristo. Esta noção abrange as verdades cristológicas já explícitas nos capítulos ante- 
riores, mas enfatiza também o exercício da caridade cristã na sociedade atual. A Igreja "não pode nem deve ficar à margem na luta pela justiça" (Bento XVI, Deus Caritas est 28), a Igreja deve defender a dignidade humana ameaçada, deve manter e revigorar sua opção preferencial pelos pobres, já implícita em sua fé cristológica (Bento XVI, Alocução Inaugural 3), sabendo que o cuidado dos pobres "caracteriza de modo decisivo a vida cristã, o estilo eclesial e a programação pastoral" (NMI 49). Urge estarmos mais perto deles, fazer-nos seus amigos, para que tenham incidência em nosso comportamento e influam nas estruturas e nas prioridades pastorais.

Numa linha mais ampla se examina a responsabilidade da Igreja na promoção humana integral, sobretudo devido ao impacto da globalização em nossos povos; na reabilitação ética da vida política; na participação maior da sociedade civil no espaço público; na luta por uma maior justiça internacional. E termina este capítulo apontando os rostos sofredores de hoje: meninos de rua, enfermos, dependentes de droga, migrantes e encarcerados (cap. VIII). Ainda dentro do amplo tema da vida se examinam várias classes de pessoas e de realidades, que hoje experimentam novos desafios: o matrimônio e a família, as crianças, os jovens, os idosos, as mulheres, os homens, a defesa da vida especialmente dos nascituros e o cuidado com o meio ambiente (cap. IX).

A vida está intimamente relacionada com a cultura que engloba num capítulo final uma série de temas como a inculturação da fé e a evangelização da cultura, a educação como bem público, a pastoral da comunicação social, os novos areópagos e centros de decisão, a maior participação do laicato na vida pública, a pastoral urbana, a integração latino-americana, a inclusão dos indígenas e afrodescendentes em nossa sociedade e a evangelização como fonte de reconciliação e de solidariedade no continente (cap. X).

Todo o documento está atravessado por um dinamismo, presente em cada página, raiz de muitas afirmações, anseio de todos os participantes: que a Igreja de Deus neste continente seja realmente uma Igreja missionária! É este dinamismo que possibilitará as mudanças necessárias, o maior espaço concedido ao laicato, a renovação do serviço presbiteral e episcopal, a opção efetiva pelos pobres, a experiência da pertença a uma comunidade eclesial, a aceitação da diversidade na Igreja, a vida de fé e de oração, a participação consciente na eucaristia, a atitude crítica face à cultura individualista, o zelo missionário, enfim a alegria profunda por sermos discípulos missionários de Jesus Cristo!

Mario de França Miranda SJ

Doutor pela Pontifícia Universidade Gregoriana Professor do Departamento de Teologia da PUC-Rio 